\title{
Estimated exposure to EU regulated mycotoxins and risk characterization of aflatoxin-induced hepatic toxicity through the consumption of the toasted cereal flour called "gofio", a traditional food of the Canary Islands (Spain)
}

\section{INTRODUCTION}

Products from agriculture, particularly cereals, are susceptible to infestation by various species of microscopic fungi (Aspergillus, Penicillium, Fusarium, and Claviceps spp.), which can produce mycotoxins directly on the plant before harvest, during harvesting, during storage, during processing, or during storage of the processed foods (Oliveira et al., 2014). More than 400 different mycotoxins are known, and most mycotoxins are immunosuppressive agents and some are carcinogens, hepatotoxins, nephrotoxins, and neurotoxins (Marroquin-Cardona et al., 2014). Various mycotoxins are specially worrisome because of their powerful toxic properties, so that they can pose a danger to public health, and are of great concern because large economic losses resulting from their presence (Rubert et al., 2013). Among mycotoxins with the greatest toxicological relevance, as well as those that produce the greatest economic losses to the agricultural sector, aflatoxins (AFs), ochratoxins (OTs), fumonisins (FBs), trichothecenes, and zearalenone (ZEA) are probably the most relevant (Azaiez et al., 2015; MarroquinCardona et al., 2014). There are currently ten mycotoxins that are regulated in the European Union (EU) because of their high toxicity $\left(\mathrm{AFB}_{1}, \mathrm{AFB}_{2}, \mathrm{AFG}_{1}, \mathrm{AFG}_{2}\right.$, Deoxynivalenol (DON), $\mathrm{FB}_{1}, \mathrm{FB}_{2}$, Ochratoxin A (OTA), ZEA, and patulin). For all of 
them, except for patulin, maximum limits (MLs) are set in cereals, both raw and processed (Table 1), giving approximately 50 mycotoxin/matrix combinations (EC, 2006). There is also a recommendation of the European Commission for an extension to T2 and HT2 trichothecenes, which also proposes limits for these mycotoxins in cereal flours and their first-processing derivatives (except rice) (Table 1) (EC, 2013).

According the FAO, in Western Europe cereals take a second position among the staples in the average diet, accounting for around $26 \%$ in terms of total energy supply (Alexy et al., 2010). In many societies the cereal staples of the diet consist on different types of flours (Ranum et al., 2014). In the Canary Islands (Spain) food called "gofio" is a non-sifted flour made from roasted grain, usually wheat or corn, which is used in a variety of food preparations, although mostly consumed as breakfast cereals. It has been a staple food for the population of the archipelago for centuries (Hernandez et al., 2014), and is still the most traditional food of the Canary Islands. This staple is consumed regularly by many of the 2.5 million inhabitants of the archipelago and occasionally by the more than 10 million tourists receiving these islands annually (Caballero et al., 2014; Hernandez et al., 2014). This food is so important, that the Canary Islands government has approved the designation of origin "Gofio Canario" under the EEC Regulation 2081/92 on designations of origin and geographical indications for agricultural and food products (EEC, 1992; Hernandez et al., 2014). In addition to the valuable nutritional properties of this cereal flour (Caballero et al., 2014), DominguezRodriguez et al. (2015) investigated its cardioprotective role, and found that the regular consumption of gofio is associated to an increase of resistance to exercise 
and a decrease of the coronary risk in the elderly (Dominguez-Rodriguez et al., 2015). Unfortunately, in a recent study investigating the presence of mycotoxins (fumonisins) in more than 1200 samples of cereal-based foods from three European countries, the authors found the highest concentrations and incidence of these mycotoxins in the samples of gofio (Rubert et al., 2013). However, it is also worth to note that all the samples of gofio included in that study were from organic production, and it has been established that the prevalence of certain types of mycotoxins, such as those produced by Fusarium spp., is higher in cereals from organic agriculture (Serrano et al., 2013).

According to the EFSA, monitoring studies evaluating the presence of mycotoxins in the different types of foods that can contain them are a continuous necessity, to allow the risk characterization associated to those food commodities (EFSA, 2013a, 2014). EFSA recommends that risk characterization of a particular food is made by comparing exposure scenarios with reference doses of the parent compounds, using the lower bound (LB) and upper bound (UP) approaches, and considering the mean and $95^{\text {th }}$ percentile exposures to the sum of modified and parent toxins (EFSA, 2014). Following the recommendations the calculated exposure values should be compared with the established Tolerable Daily Intakes (TDIs)/Provisional TDIs (PTDIs)/Provisional Maximum TDIs (PMTDIs) in order to evaluate the risk of exposure through the consumption of a particular food (Yogendrarajah et al., 2014). For most regulated mycotoxins the TDIs have been calculated (Marroquin-Cardona et al., 2014), except for aflatoxins, because of the known fact that $\mathrm{AFB}_{1}$ is a genotoxic carcinogen, and therefore exposure at any level is considered unsafe (Yogendrarajah et al., 2014). However, despite its 
uncertainty a PMTDI of $1 \mathrm{ng} / \mathrm{kg}$ B.W./day has been proposed for $\mathrm{AFB}_{1}$ (WHO, 1998). For the rest of regulated mycotoxins associated with cereal-based commodities, the reference values set by the EFSA are: DON $=1000 \mathrm{ng} / \mathrm{kg}$ B.W./day (TDI) (EFSA, 2013b); $\mathrm{FB}_{1}+\mathrm{FB}_{2}=2000$ ng/kg B.W./day (PMTDI) (EFSA, 2014); OTA = 17.1 ng/kg B.W./day (PTDI derived from the PTWI) (EFSA, 2006); $\mathrm{ZEA}=250$ ng/kg B.W./day (TDI) (EFSA, 2011b); T-2 + HT-2 = 100 ng/kg B.W./day (TDI) (EFSA, 2011a).

Although there is a wide range of publications on the occurrence of mycotoxins in cereal based foods available in Europe, as well as on the risks associated with the consumption of the same, there is no study of this type available for the gofio. Therefore, the present study aims to evaluate the presence of multiple mycotoxins in this food commodity and the charanterization of the risks associated with the intake of this staple of the Canary Islands.

\section{MATERIALS AND METHODS}

\subsection{Sampling}

A total of ninety-four packages of gofio (1 kg) were randomly purchased from different retail outlets located in the seven Canary Islands. None of the samples had surpassed their expiration date. The chosen gofio samples were made from corn $(n=45)$; wheat $(n=23)$; and mixture of the two cereals $(n=26)$. Seventy-two samples were from conventional production (37 corn, 19 wheat, 16 mixture of cereals), and 22 samples were from organic production (8 corn, 4 wheat, 10 
mixture of cereals). Until sample preparation they were stored in a dark and dry environment at room temperature.

\subsection{Chemicals and reagents}

Mycotoxin standards, including $\mathrm{AFB}_{1}, \mathrm{AFB}_{2}, \mathrm{AFG}_{1}, \mathrm{AFG}_{2}, \mathrm{FB}_{1}, \mathrm{FB}_{2}, \mathrm{OTA}, \mathrm{DON}$, and ZEA were supplied by Sigma (Sigma-Aldrich, Alcobendas, Spain). Solvents (acetonitrile and methanol), formic acid, and ammonium formate were of LCMS quality and were purchased from Merck (Darmstadt, Germany). Ultrapure (UP) water was produced in the laboratory using a Milli-Q Gradient A10 apparatus (Millipore, Molsheim, France). $0.22 \mu \mathrm{m}$ PFTE syringe filters were purchased from Macherey-Nagel (Düren, Germany). In this method, the stable isotope dilution for quantification using uniformly (13 C)-labeled mycotoxins as internal standards (ISs) was used. (Varga et al., 2012)ํ․ Thus we purchased the LC-MS Mycotoxin Kit (Romer Labs Diagnostic GmbH, Tulln, Austria), which contains a mixture of $\left({ }^{13} \mathrm{C}\right)$ labeled mycotoxins: fumonisin $\mathrm{B}_{1}$ and $\mathrm{B}_{2}$, Fusarium toxins (DON, ZEA T-2, and HT2 toxin), aflatoxins $\left(\mathrm{AFB}_{1}, \mathrm{AFB}_{2}, \mathrm{AFG}_{1}\right.$, and $\left.\mathrm{AFG}_{2}\right)$, and OTA in acetonitrile.

For the preparation of standard solutions of mycotoxins, $\mathrm{AFB}_{1}, \mathrm{AFB}_{2}, \mathrm{AFG}_{1}, \mathrm{AFG}_{2}$, $\mathrm{FB}_{1}, \mathrm{FB}_{2}$, OTA, DON, and ZEA were dissolved in methanol at a concentration of 1 $\mathrm{mg} / \mathrm{mL}$ and stored at $-20^{\circ} \mathrm{C}$ in a sealed vial until use. An intermediate solution at 1 $\mu \mathrm{g} / \mathrm{mL}$ in acetonitrile was prepared and stored at $4^{\circ} \mathrm{C}$. Working standards $(100,20$, $10,5,1,0.5,0.1,0.05,0.01$ and $0.005 \mathrm{ng} / \mathrm{ml}$ ) were prepared by appropriate

dilution of known volumes of the intermediate solution with mobile phase and 
used to obtain calibration curves in the chromatographic system. All working standards were renewed every two weeks.

\subsection{Mycotoxin extraction from gofio samples}

Five grams of gofio were placed in 50-ml Falcon tubes and mixed with $20 \mathrm{ml}$ of the extractant solution A (acetonitrile/water/formic acid: 80/19.9/0.1 v/v/v) for 60 min using a rotary shaker (Ovan RollerMix, Barcelona, Spain). After this the tubes were centrifuged at $3500 \mathrm{rpm}$ (5000 x g) for $5 \mathrm{~min}$ (Eppendorf Centrifuge $5804 \mathrm{R}$, Hamburg, Germany), and the supernatant was recovered into a new plastic tube. The gofio was subjected to a second extraction using $20 \mathrm{ml}$ the extractant solution B (acetonitrile/water/formic acid: 20/79.9/0.1 v/v/v) for $30 \mathrm{~min}$ using the rotary shaker for the recovery of Fumonisins. The tubes were centrifuged at $3500 \mathrm{rpm} \times 5$ min, and the supernatant was combined with the previously obtained one. The combined supernatants were subjected to a new centrifugation $(3500 \mathrm{rpm} \times 5$ min), and transferred to a new tube for solvent evaporation under gentle $\mathrm{N}_{2}$ stream. The dry residue was immediately reconstituted in $1 \mathrm{ml}$ of acetonitrile/water/formic acid: 50/49.9/0.1 v/v/v, and were transferred to a

HPLC vial. Finally, $20 \mu \mathrm{l}$ of $\left({ }^{13} \mathrm{C}\right)-\mathrm{ISs}(10 \mathrm{ng} / \mathrm{ml})$ were added to each vial and were subjected to chromatographic analysis without further purification steps.

\subsection{Analytical method}

The mycotoxin LC-MS/MS analyses were performed with an Agilent 1290 UHPLC tandem coupled to an Agilent 6460 mass spectrometer. The chromatographic 
separations were performed using a Zorbax Eclipse Plus C18 UHPLC column (2.1 x $150 \mathrm{~mm}, 1.8 \mu \mathrm{m})$. The mobile phase A consisted on $0.1 \%$ formic acid, $5 \mathrm{mM}$ ammonium formate in water, and the mobile phase B consisted on $0.1 \%$ formic acid, $5 \mathrm{mM}$ ammonium formate in methanol. A binary gradient using mobile phases A and B was programmed as follows: $0 \rightarrow 0.5 \mathrm{~min}, 30 \% \mathrm{~B} ; 8 \mathrm{~min}, 100 \% \mathrm{~B} ; 8$ $\rightarrow 9.5 \mathrm{~min}, 100 \% \mathrm{~B} ; 9.6 \mathrm{~min}, 30 \% \mathrm{~B}$. The flow rate was set at $0.3 \mathrm{ml} / \mathrm{min}$. The injection volume was $5 \mu \mathrm{l}$.

Transitions and conditions for the native and labeled mycotoxins were optimized using the Agilent MassHunter Optimizer software with flow injection of the diluted stock solutions (see Supplementary Table 1). For all the mycotoxins, the $[\mathrm{M}+\mathrm{H}]^{+}$ species produced the most abundant precursor ion, except for ZEA, which achieved the highest sensitivity in negative mode with $[\mathrm{M}-\mathrm{H}]^{-}$as the precursor. The MS/MS ionization was performed with a Jet Stream electrospray ionization (ESI). Two MS/MS transitions were optimized for each analyte for identification and quantification purposes. Nitrogen was used as nebulizer and collision gas. The operating conditions for the analyses in positive and negative ESI were the following: gas temperature $140^{\circ} \mathrm{C}$; nebulizer gas flow $16 \mathrm{~L} / \mathrm{min}$; Nebulizer pressure 25 psi; Sheath gas temperature $350{ }^{\circ} \mathrm{C}$; Sheath gas flow $11 \mathrm{~L} / \mathrm{min}$; Capillary voltages 4,000 V (positive); 3,000 V (negative); Cycle time 400 ms; Dwell time $50 \mathrm{~ms}$.

\subsection{Validation of the analytical method}


The analytical method was assessed for selectivity, linearity, precision, and repetitiveness (see Supplementary Table 2). Selectivity was checked by injecting 5 $\mu \mathrm{l}$ of mycotoxin standard solution three times before injecting extracted samples and comparing the peak retention time, and the ion ratio of the transitions of each mycotoxin. Standard curves were generated by linear regression of peak areas against concentrations. Precision was established by determining the levels of the targeted mycotoxins in fortified gofio samples by triplicate.

\subsection{Exposure assessment}

In order to estimate the probability and severity of potential adverse health effects of the presence of targeted mycotoxins in gofio, a quantitative exposure assessment was performed considering two populations: adults (18 years old and above), and children (6 to 10 years old) from the Canary Islands. The estimated daily intakes (EDIs) were obtained by the combination of mycotoxin analysis with the gofio consumption data as reported in the Canary Islands Nutritional Survey (ENCA) (Serra Majem et al., 2000). Since according to ENCA there are no significant differences in the consumption of gofio between men and women or boys and girls, exposure by gender was not taken into consideration. For each age category the exposure was assessed using the median value of consumption and the median value of mycotoxin concentrations in gofio. As recommended by the EFSA we also considered the substitution of the censored data and we summarize the results as a range, with a lower bound (ND $=0$, which means that all contamination results below the LOD were substituted by 0) and an upper bound (ND = LOD, which means that all contamination results below the LOQ were 
substituted by the corresponding LOD) (EFSA, 2013a). Also following the EFSA recommendations exposure calculations at the 95 th percentile (P95) of consumption were performed with the aim of evaluating the worst-case scenarios (EFSA, 2013a, 2014).

The EDIs (ng/kg b.w./day) of each mycotoxin were calculated as indicated in the Equation 1 (Azaiez et al., 2015; Rodríguez-Hernández et al., 2015a; RodríguezHernández et al., 2015b):

$$
\mathrm{EDI}=(\mathrm{C} \times K) / \text { b.w. } \quad \text { (Equation 1) }
$$

Where $\mathrm{C}$ is the median content (and range) of a mycotoxin (ng/g); $\mathrm{K}$ is the median or $95^{\text {th }}$ percentile value of consumption of gofio in a given age group and scenario (g/day); and b.w. is the average body weight of either, adults $(70.1 \mathrm{~kg}$ ) and children (30.4 kg) from the Canary Islands.

To evaluate the risk of exposure through the consumption of gofio, we calculated the percentage of the TDI or PTDI that this exposure represents in each age group and scenario. These percentages were also calculated when the censored data were substituted as previously defined, and the results were presented as a range with a LB and a UB. The calculations were done using the Equation 2 as follows:

$$
\% \mathrm{TDI}=(\mathrm{EDI} / \mathrm{TDI}) \times 100 \quad \text { (Equation } 2)
$$


Where we used the TDIs/PTDIs or derived PTDIs from PTWIs of each mycotoxin as detailed above.

\subsection{Risk characterization}

This final step of risk assessment integrates dose-response and exposure data to describe the overall nature and magnitude of risk. Aflatoxins have been classified as carcinogenic to humans (group 1 IARC) (IARC, 2002). The weight of evidence for the classification of the aflatoxins as Group-1 carcinogens was driven by statistically significantly increased risks for hepatocellular carcinoma (HCC) in individuals exposed to aflatoxins. This effect was independent of exposure to hepatitis B virus (HBV); however, it has been also established that a greater than multiplicative interaction between aflatoxin exposure and HBV infection exists (IARC, 2002; Liu and Wu, 2010). Considering this fact, and also the results of this study (detailed below), we focused the risk characterization only in the burden of aflatoxin-related liver cancer.

The increased cancer risk from a lifetime oral exposure to a carcinogenic agent can be calculated according to the Equation 3 (USEPA, 2005):

$$
\text { Risk = EDI } x \text { CPS } x \text { (number of years of life) } \quad \text { (Equation 3) }
$$

Where EDI is the adult individual's lifetime estimated daily intake of the carcinogen (i.e. aflatoxin), and CPS is the carcinogenic potency slope for ingestion. In this study we used two values of CPS as defined by the Joint FAO/WHO Expert 
Committee on Food Additives (JECFA, 1998; Liu and Wu, 2010): 0.3 cancers per year per $10^{5}$ population per nanogram of $\sum A F s\left(A F_{1}+A F_{2}+A G_{1}+A G_{2}\right)$ per kg b.w. per day for people with positive surface antigen of hepatitis B (HBsAg+); and 0.01 cancers per year per $10^{5}$ population per nanogram of $\sum$ AFs per kg b.w. per day for people with negative surface antigen of hepatitis B (HBsAg-) (JECFA, 1998; Liu and $\mathrm{Wu}, 2010)$. For this study we have used the last available data (2013) of life expectancy of the Canary Islands inhabitants (81.8 years) as the number of years of life (ISTAC, 2013).

\subsection{Statistical analysis}

Database management and statistical analyses were performed using PASW Statistics v. 20.0 (SPSS Inc., Chicago, USA). The distribution of the variables included in this study was evaluated through Kolmogorov-Smirnov test. The concentration of the mycotoxins included in this study did not follow a normal distribution; therefore, the results are expressed in terms of the median, and range (values minimum and maximum). Differences of contaminants among groups were tested with the non-parametric Mann-Whitney U-test and Kruskal Wallis test. A $P$ value of less than 0.05 (two-tail) was considered to be statistically significant.

\section{RESULTS AND DISCUSSION}

\subsection{Method validation data}


The LC-MS chromatograms showed a good resolution for target analytes and no peaks appeared at the retention times of analytes that can interfere in their quantification. As expected using the stable isotope dilution technique for quantification, matrix effect was not observed for none of the studied mycotoxins. In Supplementary Table 2 we summarize the main data obtained from validation experiments. All the correlation coefficients $\left(\mathrm{r}^{2}\right)$ were higher than 0.99 , and the RSD lower than $15 \%$ for all the analytes The limit of detection (LOD) of each mycotoxin was considered to be the concentration that yielded a signal-to-noise ratio $>5$, and the limit of quantification (LOQ) was calculated a $3 \times$ LOD. The LODs and LOQs of the targeted mycotoxins were: AFs $=0.008 \mathrm{ng} / \mathrm{g}$ and $0.025 \mathrm{ng} / \mathrm{g}$, respectively; $\mathrm{FBs}=0.3 \mathrm{ng} / \mathrm{g}$ and $1 \mathrm{ng} / \mathrm{g}$, respectively; OTA $=0.03 \mathrm{ng} / \mathrm{g}$ and 0.1 $\mathrm{ng} / \mathrm{g}$, respectively; DON = $1.5 \mathrm{ng} / \mathrm{g}$ and $5 \mathrm{ng} / \mathrm{g}$, respectively; and ZEA $=0.012 \mathrm{ng} / \mathrm{g}$ and $0.04 \mathrm{ng} / \mathrm{g}$, respectively.

\subsection{Occurrence of mycotoxins in gofio}

Table 2 shows the concentrations of the targeted mycotoxins in the samples of gofio. In this table results (median, range and frequency) relating to all the samples considered together, and also the results grouped according to the type of raw material with which the gofio was elaborated (comparing them with each other), as well as the pooled results according the mode of production of cereal (conventional vs. organic production) were included. 
Eighty three per cent of the samples were contaminated, although in none of the samples the EU MLs (Table 1) were surpassed. Remarkably $69.2 \%$ of the samples appeared simultaneously contaminated by 2 or more mycotoxins (range 2 to 8 ).

The most frequently detected mycotoxins were fumonisins ( $\mathrm{FB}_{1}$ and $\left.\mathrm{FB}_{2}\right)$ (Table 2), which is consistent with the results of the only previous study that exists in this topic in gofio samples, where the authors found that $86.47 \%$ of the analyzed samples showed contamination by these mycotoxins (Rubert et al., 2013). However, the median values of concentration found in our study are much lower than those previously reported: range of concentrations in samples positive for FB 1 (70.2\%) from 1.2 to $140.9 \mathrm{ng} / \mathrm{g}$ in the present study, and from 812.6 to $1101.6 \mathrm{ng} / \mathrm{g}$ in the previous study; and range of concentrations in samples positive for $\mathrm{FB}_{2}(65.9 \%)$ from 2.7 to $37.4 \mathrm{ng} / \mathrm{g}$ in our study and 693.2 to $981.3 \mathrm{ng} / \mathrm{g}$ in the previous study (Rubert et al., 2013).

ZEA was the second most frequently detected mycotoxin. It was present in 40 samples $(42.5 \%$, Table 2$)$, although at very low levels, with a median concentration of only 0.02 ng/g. Considering only the positive samples the concentrations of ZEA ranged from 0.05 to $9.92 \mathrm{ng} / \mathrm{g}$. Although there are no studies in gofio with which to compare these results, it is surprising that in samples of wheat flour and maize flour marketed in Spain ZEA was not found in any of the samples investigated (Alborch et al., 2012; RodriguezCarrasco et al., 2014). This is probably due to the LOQ of our method is considerably lower than that used in the above cited works (ZEA LOQ $=0.012 \mathrm{ng} / \mathrm{g}$ vs. higher than $0.5 \mathrm{ng} / \mathrm{g})$. However, in another study where the authors analyzed samples of maize flour from the German market, they found that $62.5 \%$ of the samples were contaminated with ZEA, with a median concentration value of $12 \mathrm{ng} / \mathrm{g}$ (Reinhold and Reinhardt, 2011). It 
is likely that these higher concentrations reported in German flour are due to the fact that they come from unroasted cereal. The gofio is a type of flour that comes from cereal that is toasted at high temperatures (above $200^{\circ} \mathrm{C}$ ), as it has been shown that there is a certain degree of thermal degradation of ZEA above $200^{\circ} \mathrm{C}$ (Numanoglu et al., 2013).

DON was present in 33\% of samples gofio, with a median concentration in positive samples of $9.33 \mathrm{ng} / \mathrm{g}$ (1.43 ng/g considering all samples, Table 2). No previous studies have determined this mycotoxin in gofio samples, but if compared to studies in conventional wheat flour and maize flour (from unroasted grain), we find that the incidence and concentration (median) of DON in flours from the Spanish market is somewhat higher (55\%, $11.4 \mathrm{ng} / \mathrm{g}$ ) (Rodriguez-Carrasco et al., 2014). In a study from the German market flours authors reported lower incidence of DON contamination, but median values of concentration much higher than those found in this study in gofio (156 ng/g) (Reinhold and Reinhardt, 2011). Again it is noteworthy that the comparison of gofio with flour from unroasted cereals may not be the most appropriate, since it has been reported that DON levels decrease with thermal processes, such as baking or roasting (Vidal et al., 2015).

Aflatoxins, particularly $\mathrm{AFB}_{1}$ and $\mathrm{AFB}_{2}$, which undoubtedly are the most toxic of all the mycotoxins studied, were present at a surprisingly high percentage of samples gofio (22.3\% and $21.7 \%$, respectively), when compared with recent studies in flour samples, such as the study of Liu et al. (2015) where the authors reported only $0.28 \%$ of positive samples (one single positive sample from a total of 348 samples of wheat analyzed), or the Vidal et al. (2013) study where aflatoxins were not 
detected in the analysed samples. This probably has to do with the low LOQ of our method, since the values reported in the only positive sample of the Chinese study were quite high (8.45 ng/g) (Liu et al., 2015). In other recent studies in flours (since there are no studies in gofio) with lower LOQs the reported incidence has been higher (46.5\% and $66.7 \%$ in wheat flour and corn flour respectively) and the median concentrations were lower $(0.2 \mathrm{ng} / \mathrm{g}$ and $1.12 \mathrm{ng} / \mathrm{g}$ in wheat and corn flours, respectively) than in Chinese samples (Alborch et al., 2012; Kara et al., 2015). In any case these reported concentrations in flour are superior to those we reported in gofio (median $\mathrm{AFB}_{1}$ in positive samples $=0.07 \mathrm{ng} / \mathrm{g}$, and median $\mathrm{AFB}_{2}$ in positive samples $=0.04 \mathrm{ng} / \mathrm{g}$ ). This situation could be attributable to a certain degree of degradation of mycotoxins during the roasting process, because high temperatures may reduce the aflatoxin contents, although not get a complete elimination (Kaushik, 2015). Aflatoxins $G_{1}$ and $G_{2}$ appeared in samples gofio less commonly $(<10 \%)$, but at similar concentrations (considering only positive samples) than $\mathrm{AFB}_{1}$ and $\mathrm{AFB}_{2}$ (median values of 0.05 and 0.03 for $\mathrm{AFG}_{1}$ and $\mathrm{AFG}_{2}$, respectively).

OTA was the mycotoxin found less frequently in gofio samples. Despite the low LOQ of our method for this mycotoxin $(0.03 \mathrm{ng} / \mathrm{g})$, it was detected in only 2 samples $(2.2 \%)$ that showed concentrations of 0.22 and $0.30 \mathrm{ng} / \mathrm{g}$, respectively, bringing the median value is $0.0 \mathrm{ng} / \mathrm{g}$ for the entire series. This percentage, as well as the levels found are considerably lower than those reported for other corn flour and wheat flour samples. Alborch et al. (2013) reported an incidence of $13 \%$ and concentrations of 0.79 to $1.7 \mathrm{ng} / \mathrm{g}$ in wheat flour from various countries. Also in wheat flour samples from Turkey and England an incidence of OTA of nearly $20 \%$ 
(median $0.12 \mathrm{ng} / \mathrm{g}$ ) was reported (Beheshti and Asadi, 2013). The percentage of positive samples of corn flour was even higher according to a recent study (Algul and Kara, 2014), where the authors reported a range of concentrations from 0.37 to as much as $25.34 \mathrm{ng} / \mathrm{g}$ (median $=0.54 \mathrm{ng} / \mathrm{g}$ ). However, once again the comparison of gofio with other no thermally treated flours is not the most appropriate, because although it is known that the OTA is the most thermally stable mycotoxin because it remains unaltered up to $180^{\circ} \mathrm{C}$ (Raters and Matissek, 2008)), it has been shown that their concentration in food decreases when treated at temperatures higher than $180^{\circ} \mathrm{C}$ (Vidal et al., 2015). . This could explain the very low incidence and concentrations in gofio.

\subsubsection{Differences in mycotoxin levels due to type of cereal}

No significant statistical differences for a confidence interval of $95 \%$ in mycotoxin occurrence were observed between samples of gofio made from different raw cereals (corn vs. wheat vs. mixed cereals, Kruskall-Wallis test of comparison among groups was non significant for all mycotoxins, Table 2). This result is similar to that reported by other authors who neither found differences between flours of different cereals (Beheshti and Asadi, 2013; Kara et al., 2015; Reinhold and Reinhardt, 2011; Rodriguez-Carrasco et al., 2014).

3.2.2. Differences in mycotoxin levels due to type of production (organic vs. conventional) 
Nowadays the consumption of organic foods has increased and an increasing number of consumers demand this type of products they perceive as healthier, and even better from a nutritional standpoint. This obviously also applies to the demand for gofio in the Canary Islands. So much so that we were able include in this study up to 22 samples of organic gofio from 12 different manufacturers, because they are very present in the market. However, it has been reported that, although these products do not contain residues of pesticides, other unsafe compounds such as mycotoxins can be present in organic foods, especially in those coming from cereals since no fungicides have been used during their production (Rubert et al., 2013). Thus, it has been reported than the occurrence of various mycotoxins is superior in cereals and cereal-products from organic agriculture (D'Arco et al., 2008; Rubert et al., 2013). However other studies have indicated that, although present, the levels of mycotoxins detected in organic cereals are lower that the levels in conventional cereals (Ariño et al., 2007; Cirillo et al., 2003). For these reasons, the investigation about differences in the concentration, frequency of occurrence and co-occurrence of mycotoxins based on their mode of production were evaluated. The results of these analyses are summarized in Table 2 and in Figure 1.

Regarding AFs, our results indicate that there is no difference in either frequency or concentration between gofio of organic and conventional production, as it has been described for other cereal based foods (Hernandez-Martinez and NavarroBlasco, 2010; Vidal et al., 2013). For the rest of mycotoxins, we found any difference either in frequency, in concentration, or both (Table 2). In the case of OTA, we can not speak of statistical significance, since there were only two positive 
samples, but it is worth noting that in both cases these samples were from organic production. Fumonisins have been the most frequently investigated mycotoxins between organic and conventional cereals, and many authors have found that the levels are higher in organic foods (Ariño et al., 2007; Cirillo et al., 2003; D'Arco et al., 2008; Rubert et al., 2013). In fact, the only research work that has investigated mycotoxins in gofio focused on fumonisins in organic samples, and found that it was the type of cereal that higher frequency of detection and higher concentrations presented from more than 1200 samples investigated (Rubert et al., 2013). Unfortunately, in this paper the authors did not include conventional production samples for comparison. In our work we found no significant differences in concentration for the $\mathrm{FB}_{1}$ (median $=4.92 \mathrm{vs} .6 .19 \mathrm{ng} / \mathrm{g}$ for conventional and organic samples, respectively) or for $\mathrm{FB}_{2}$ (4.02 vs. $4.06 \mathrm{ng} / \mathrm{g}$ for conventional and organic samples, respectively). However, we did find differences in the detection frequency, as fumonisins were detected in most samples from organic production (19 out of 22 samples in the case of $\mathrm{FB}_{1}$, and in 20 out of 22 samples in the case of $\mathrm{FB}_{2}$ ). For DON and ZEA we found that both the frequency of occurrence and concentrations were higher in the gofio from organic production than in that from conventional production. With respect to DON this result is not consistent with what has been recently published for other types of flour, where the authors have either found no significant differences between modes of production (Edwards, 2009a, b; Vidal et al., 2013), or have often found that the concentration were lower in organically produced cereal (Bernhoft et al., 2010). For ZEA no significant differences have been reported in other works (Bernhoft et al., 2010; Edwards, 2009a, b; Vidal et al., 2013), unlike what we have found in samples of gofio (Table 1). 
Finally, another relevant difference between organic and conventional gofio samples is the co-occurrence of mycotoxins (Figure 1). Thus, all the samples were none mycotoxin was detected corresponded with conventional samples $(n=8)$. The average number of mycotoxins per sample was 2.5 in conventional samples and 3.7 in organically produced gofio $(P<0.05)$, and in 1 organic gofio sample as much as 8 different mycotoxins were detected.

\subsection{Exposure to mycotoxins through the consumption of gofio}

In Table 3 we have summarized the exposure to mycotoxins through the consumption of gofio for average and $95^{\text {th }}$ percentile consumers, and for two population groups (adults and children), as recommended by the EFSA (EFSA, 2013a, b, 2014). Also following the recommendations of this agency the censored data of the results were taken into account to give a range with a lower bound (where all the results below the LOD were substituted by 0), and an upper bound (where all the results below the LOQ were substituted by that LOD). It is widely considered that the LB scenario generally underestimates contamination and exposure levels and that the UB scenario overestimates them (EFSA, 2010). For these reasons, we also included the middle-bound approach (namely EDI in Table 3), where the results below the LOD were substituted by 0 , and the results below the LOQ but above the LOD were substituted by the LOD). For all estimates we calculated the percentage of TDI/PTDI which represents the daily intake of each mycotoxin through the consumption of this food (Table 3). 
As observed in Table 3 for most mycotoxins (FBs, OTA, DON, and ZEA), when we considered the most realistic middle-bound approach, the EDI did not reach even the $1 \%$ of the established tolerable values, even in the case of high consumers of gofio, neither for adults nor for children. However, it is noteworthy that in the worst-case scenario FBs and DON would surpass $10 \%$ of the respective TDIs in both age groups, which could be considered somewhat worrying, as we are considering only one food source. These results of intake are similar to those recently estimated for breakfast cereals in Portugal (Assuncao et al., 2015). We have considered pertinent to mention this, as breakfast cereals are also frequently consumed in the Canary Islands, and the consumption of gofio would be complementary, as it is frequently consumed in the breakfast, and would add mycotoxin exposure to this intake of breakfast cereals and other cereal-based foods, such as bread (De Boevre et al., 2013).

Special mention deserves the intake of aflatoxins through gofio, as being the most toxic of all the mycotoxins included in this study it is also the one that brings greater percentage of its TDI. As shown in Table 3 for average consumers, the gofio contributes $2.3 \%$ and $3.7 \%$ of aflatoxin TDI for adults and children respectively, and more than doubled for consumers in the 95th percentile. It should be borne in mind that in this group of consumers, if we consider the estimates of the upper bound, the percentage of the TDI could be as high as 36\%, which can be considered worrisome if we take into account that we are analyzing a single food of the usual diet of the inhabitants of the Canary Islands. In recent studies in breakfast cereals and other cereal-based foods the authors have estimated levels of exposure for aflatoxins, which are similar to those reported in this paper for gofio (from 0.011 
to $0.020 \mathrm{ng} / \mathrm{kg}$ bw/day in studies in Portugal, France, and Spain) (Assuncao et al., 2015; De Boevre et al., 2013; Sirot et al., 2013). In these cases, the authors concluded that the exposure to these levels of aflatoxins could represent a longterm health problem for those consumers in the P90, P95, and P99. We should note that in the case of many the consumers of the Canary Islands the exposure to aflatoxins through gofio would add to that coming from the consumption of other cereals which are consumed in Spain (Michels et al., 2016).

\subsection{Risk characterization for liver cancer associated to aflatoxin contamination in gofio}

As mentioned above, aflatoxins (particularly $\mathrm{AFB}_{1}$ ) are potent human carcinogens that have been linked to the development of liver cancer. It has been also established that these mycotoxins act synergistically with other known hepatocarcinogens, so that it has been established a strong influence of this mycotoxin in the high incidence of this cancer in several countries, especially in developing countries (Yogendrarajah et al., 2014). According to the estimates of JECFA and independent researchers, the risk of liver cancer in individuals who are simultaneously exposed to hepatocellular virus type B (HBV) and aflatoxin is 30 times higher than in individuals exposed to aflatoxins only (JECFA, 1998; Liu and $\mathrm{Wu}, 2010$; Yogendrarajah et al., 2014). Estimates of prevalence of HBV in Western Europe (including Spain) range from $0.5-1 \%$ depending on the age group (Liu and $\mathrm{Wu}, 2010$ ), which would mean that between 12500 and 25000 people in the Canary Islands are affected. 
Given the chronic prevalence of HBV values in the Canary Islands, the risks of induction of liver cancer were calculated due to aflatoxin exposure through consumption of gofio both in population exposed and not exposed to HBV. Again we considered two population groups: children and adults.

For cancer risk assessment, it is traditionally assumed that there is no threshold of exposure to a carcinogen below which there is no observable adverse effect. However, for the purposes of the characterization of this risk we used the cancer potency factors estimated from the slope of the dose-response relationship, which is assumed to be linear, between doses of the carcinogen and cancer incidence in a population, which have been defined for HBsAg- and HBsAg+ populations (JECFA, 1998; Liu and $\mathrm{Wu}, 2010)$. When we apply the Equation 3 for risk calculation we obtain a numeric value, and we assume that if the value of risk is equal to or less than 1 , then it can be considered that there is no increased risk of liver cancer that may be attributable to exposure to aflatoxins through the consumption of gofio.

Figure 2 graphically represent the results of the risk characterization. According to our calculations the risk to the population not exposed to HBV is not increased due to the consumption of gofio (risks $=0.028$ and 0.044 for adults and children, respectively). However, for HBsAg+ population the risk is much higher, approaching 1 in the case of the adult population $(0.9793)$ and greater than 1 in the case of children $(1,527)$.

\section{CONCLUSIONS}


The results of this study revealed that the levels of mycotoxins in gofio imply a low daily intake $(<1 \%$ TDI) for the average consumer, except in the case of aflatoxins. However, in the worst-case scenario (intense consumers and UB approach) a relevant percentage of the TDI $(\sim 10 \%)$ is reached for FBs and DON, and a high percentage of TDI ( $>35 \%$ ) is reached for AFs. Worringly, our results indicate that there may be a potential risk in developing liver cancer due to AFs exposure via gofio in a particularly sensitive population group, which is that of children chronically exposed to $\mathrm{HBV}$, and therefore this result have been transferred to risk managers, who are currently planning the implementation of possible measures intended to reduce the content in aflatoxins in gofio. Our results indicate that future studies on the critical control points (production procedure, handling, packing, transportation and storage) of this staple of the population of the Canary Islands are needed, and that the reevaluation of these results should be done in the future to verify the effectiveness of the measures taken.

\section{FIGURE LEGENDS}

Figure 1. Number of samples co-contaminated with different mycotoxins.

Figure 2. Lifetime cancer risk derived from the exposure to aflatoxins through the consumption of gofio.

\section{REFERENCES}

Alborch, L., Bragulat, M.R., Castella, G., Abarca, M.L., Cabanes, F.J., 2012. Mycobiota and mycotoxin contamination of maize flours and popcorn kernels for human consumption commercialized in Spain. Food Microbiol 32, 97-103. 
Alexy, U., Zorn, C., Kersting, M., 2010. Whole grain in children's diet: intake, food sources and trends. Eur J Clin Nutr 64, 745-751.

Algul, I., Kara, D., 2014. Determination and chemometric evaluation of total aflatoxin, aflatoxin B1, ochratoxin A and heavy metals content in corn flours from Turkey. Food chemistry 157, 70-76.

Ariño, A., Estopañan, G., Juan, T., Herrera, A., 2007. Estimation of dietary intakes of fumonisins B1 and B2 from conventional and organic corn. Food Control 18, 10581062.

Assuncao, R., Vasco, E., Nunes, B., Loureiro, S., Martins, C., Alvito, P., 2015. Singlecompound and cumulative risk assessment of mycotoxins present in breakfast cereals consumed by children from Lisbon region, Portugal. Food and chemical toxicology : an international journal published for the British Industrial Biological Research Association 86, 274-281.

Azaiez, I., Font, G., Mañes, J., Fernández-Franzón, M., 2015. Survey of mycotoxins in dates and dried fruits from Tunisian and Spanish markets. Food Control 51, 340346.

Beheshti, H.R., Asadi, M., 2013. Ochratoxin A in several grains in Iran. Food additives \& contaminants. Part B, Surveillance 6, 200-202.

Bernhoft, A., Clasen, P.E., Kristoffersen, A.B., Torp, M., 2010. Less Fusarium infestation and mycotoxin contamination in organic than in conventional cereals. Food Addit Contam Part A Chem Anal Control Expo Risk Assess 27, 842-852.

Caballero, J.M., RTejera, R.L., Caballero, A., Rubio, C., González-Weller, D., Gutierrez, A.J., Hardisson, A., 2014. Composición mineral de los distintos tipos de gofio canario; factores que afectan a la presencia de $\mathrm{Na}, \mathrm{K}, \mathrm{Mg}, \mathrm{Ca}, \mathrm{Mn}, \mathrm{Fe}, \mathrm{Cu}$ y $\mathrm{Zn}$ Nutricion hospitalaria 29, 687-694.

Cirillo, T., Ritieni, A., Visone, M., Cocchieri, R.A., 2003. Evaluation of conventional and organic italian foodstuffs for deoxynivalenol and fumonisins $B(1)$ and $B(2)$. J Agric Food Chem 51, 8128-8131.

D'Arco, G., Fernandez-Franzon, M., Font, G., Damiani, P., Manes, J., 2008. Analysis of fumonisins $\mathrm{B}(1), \mathrm{B}(2)$ and $\mathrm{B}(3)$ in corn-based baby food by pressurized liquid extraction and liquid chromatography/tandem mass spectrometry. J Chromatogr A $1209,188-194$.

De Boevre, M., Jacxsens, L., Lachat, C., Eeckhout, M., Di Mavungu, J.D., Audenaert, K., Maene, P., Haesaert, G., Kolsteren, P., De Meulenaer, B., De Saeger, S., 2013. Human exposure to mycotoxins and their masked forms through cereal-based foods in Belgium. Toxicology letters 218, 281-292. 
Dominguez-Rodriguez, A., Avanzas, P., Abreu-Gonzalez, P., Gonzalez-Gonzalez, J., Del Carmen Garcia-Baute, M., Barrios, P., Martin-Cabeza, M., Jimenez-Sosa, A., 2015. Consumption of 'gofio', a roasted cereal flour from the Canary Islands, is associated with exercise capacity and risk of coronary heart disease in the elderly. Int J Cardiol 187, 41-43.

EC, 2006. Comission Regulation (EC) No 1881/2006 of 19 December 2006 setting maximum levels for certain contaminants in foodstuffs. Off J Eur Union, L364/365L364/324.

EC, 2013. Commission Recommendation of 27 March 2013 on the presence of T-2 and HT-2 toxin in cereals and cereal products. Off J Eur Union L91/12

Edwards, S.G., 2009a. Fusarium mycotoxin content of UK organic and conventional oats. Food Addit Contam Part A Chem Anal Control Expo Risk Assess 26, 10631069.

Edwards, S.G., 2009b. Fusarium mycotoxin content of UK organic and conventional wheat. Food Addit Contam Part A Chem Anal Control Expo Risk Assess 26, 496506.

EEC, 1992. Council Regulation (EEC) No 2081/92 on the protection of geographical indications and designations of origin for agricultural products and foodstuffs. Off J Eur Union 208, 1-8.

EFSA, 2006. Opinion of the scientific panel on contaminants in the food chain on a request from the Commission related to ochratoxin A in food. EFSA journal 365, 156.

EFSA, 2010. Management of left-censored data in dietary exposure assessment of chemical substances. EFSA journal 8, 1-96.

EFSA, 2011a. Scientific Opinion on the risks for animal and public health related to the presence of T-2 and HT-2 toxin in food and feed. EFSA journal 9, 1-185.

EFSA, 2011b. Scientific Opinion on the risks for public health related to the presence of zearalenone in food. EFSA journal 9, 1-123.

EFSA, 2013a. Aflatoxins (sum of B1, B2, G1, G2) in cereals and cereal-derived food products. EFSA Supporting Publications EN-406, 1-11.

EFSA, 2013b. Deoxynivalenol in food and feed: occurrence and exposure. EFSA journal 11, 1-56.

EFSA, 2014. Scientific Opinion on the risks for human and animal health related to the presence of modified forms of certain mycotoxins in food and feed. EFSA journal 12, 1-107. 
Hernandez, O.M., Fraga, J.M., Jimenez, A.I., Jimenez, F., Arias, J.J., 2014. Characterization of toasted cereal flours from the Canary Islands (gofios). Food chemistry 151, 133-140.

Hernandez-Martinez, R., Navarro-Blasco, I., 2010. Aflatoxin levels and exposure assessment of Spanish infant cereals. Food additives \& contaminants. Part B, Surveillance 3, 275-288.

IARC, 2002. IARC Monographs on the evaluation of the carcinogenic risk of chemicals to humans. Aflatoxins. World Health Organization, Lyon. 1-130. Available at

ISTAC, 2013. Instituto Canario de Estadística. Esperanzas de vida de residentes in: G.d. Canarias (Ed.). Gobierno de Canarias, Santa Cruz de Tenerife.

JECFA, 1998. Joint FAO/WHO Expert Committee on Food Additives. Safety Evaluation of Certain Food Additives and Contaminants. WHO Food additives series 40. World Health Organization.

Kara, G.N., Ozbey, F., Kabak, B., 2015. Co-ocurrence of aflatoxins and ochratoxin A in cereal flours commercialised in Turkey. Food Control 54, 275-281.

Kaushik, G., 2015. Effect of processing on mycotoxin content in grains. Critical reviews in food science and nutrition 55, 1672-1683.

Liu, Y., Lu, Y., Wang, L., Chang, F., Yang, L., 2015. Survey of 11 mycotoxins in wheat flour in Hebei province, China. Food additives \& contaminants. Part B, Surveillance $8,250-254$.

Liu, Y., Wu, F., 2010. Global burden of aflatoxin-induced hepatocellular carcinoma: a risk assessment. Environ Health Perspect 118, 818-824.

Marroquin-Cardona, A.G., Johnson, N.M., Phillips, T.D., Hayes, A.W., 2014. Mycotoxins in a changing global environment--a review. Food and chemical toxicology : an international journal published for the British Industrial Biological Research Association 69, 220-230.

Michels, N., De Henauw, S., Beghin, L., Cuenca-Garcia, M., Gonzalez-Gross, M., Hallstrom, L., Kafatos, A., Kersting, M., Manios, Y., Marcos, A., Molnar, D., Roccaldo, R., Santaliestra-Pasias, A.M., Sjostrom, M., Reye, B., Thielecke, F., Widhalm, K., Claessens, M., 2016. Ready-to-eat cereals improve nutrient, milk and fruit intake at breakfast in European adolescents. European journal of nutrition 55, 771-779.

Numanoglu, E., Yener, S., Gokmen, V., Uygun, U., Koksel, H., 2013. Modelling thermal degradation of zearalenone in maize bread during baking. Food Addit Contam Part A Chem Anal Control Expo Risk Assess 30, 528-533. 
Oliveira, P.M., Zannini, E., Arendt, E.K., 2014. Cereal fungal infection, mycotoxins, and lactic acid bacteria mediated bioprotection: from crop farming to cereal products. Food Microbiol 37, 78-95.

Ranum, P., Pena-Rosas, J.P., Garcia-Casal, M.N., 2014. Global maize production, utilization, and consumption. Ann N Y Acad Sci 1312, 105-112.

Raters, M., Matissek, R., 2008. Thermal stability of aflatoxin B1 and ochratoxin A. Mycotoxin Res 24, 130-134.

Reinhold, L., Reinhardt, K., 2011. Mycotoxins in foods in Lower Saxony (Germany): results of official control analyses performed in 2009. Mycotoxin Res 27, 137-143.

Rodriguez-Carrasco, Y., Molto, J.C., Berrada, H., Manes, J., 2014. A survey of trichothecenes, zearalenone and patulin in milled grain-based products using GCMS/MS. Food chemistry 146, 212-219.

Rodríguez-Hernández, A., Boada, L.D., Almeida-González, M., Mendoza, Z., RuizSuárez, N., Valerón, P.F., Camacho, M., Zumbado, M., Henríquez-Hernández, L.A., Luzardo, 0.P., 2015a. An estimation of the carcinogenic risk associated with the intake of multiple relevant carcinogens found in meat and charcuterie products. The Science of the total environment 514, 33-41.

Rodríguez-Hernández, A., Boada, L.D., Mendoza, Z., Ruiz-Suárez, N., Valerón, P.F., Camacho, M., Zumbado, M., Almeida-González, M., Henríquez-Hernández, L.A., Luzardo, O.P., 2015b. Consumption of organic meat does not diminish the carcinogenic potential associated with the intake of persistent organic pollutants (POPs). Environmental science and pollution research international.

Rubert, J., Soriano, J.M., Manes, J., Soler, C., 2013. Occurrence of fumonisins in organic and conventional cereal-based products commercialized in France, Germany and Spain. Food and chemical toxicology : an international journal published for the British Industrial Biological Research Association 56, 387-391.

Serra Majem, L., Armas Navarro, A., Ribas Barba, L., 2000. [Food consumption and food sources of energy and nutrients in Canary Islands (1997-98)]. Archivos latinoamericanos de nutricion 50, 23-33.

Serrano, A.B., Font, G., Manes, J., Ferrer, E., 2013. Emerging Fusarium mycotoxins in organic and conventional pasta collected in Spain. Food and chemical toxicology : an international journal published for the British Industrial Biological Research Association 51, 259-266.

Sirot, V., Fremy, J.M., Leblanc, J.C., 2013. Dietary exposure to mycotoxins and health risk assessment in the second French total diet study. Food and chemical toxicology : an international journal published for the British Industrial Biological Research Association 52, 1-11. 
USEPA, 2005. Guidelines for carcinogen risk assessment. U.S. Environmental Protection Agency. 1-166. Available at

Varga, E., Glauner, T., Koppen, R., Mayer, K., Sulyok, M., Schuhmacher, R., Krska, R., Berthiller, F., 2012. Stable isotope dilution assay for the accurate determination of mycotoxins in maize by UHPLC-MS/MS. Anal Bioanal Chem 402, 2675-2686.

Vidal, A., Marin, S., Ramos, A.J., Cano-Sancho, G., Sanchis, V., 2013. Determination of aflatoxins, deoxynivalenol, ochratoxin $A$ and zearalenone in wheat and oat based bran supplements sold in the Spanish market. Food and chemical toxicology : an international journal published for the British Industrial Biological Research Association 53, 133-138.

Vidal, A., Sanchis, V., Ramos, A.J., Marin, S., 2015. Thermal stability and kinetics of degradation of deoxynivalenol, deoxynivalenol conjugates and ochratoxin A during baking of wheat bakery products. Food chemistry 178, 276-286.

WHO, 1998. Safety Evaluation of Certain Food Additives and Contaminants. Series No. 40. Food Additives. Geneva: WHO; 1998. pp. 359-469. Food Additives Series 40, 359-469.

Yogendrarajah, P., Jacxsens, L., Lachat, C., Walpita, C.N., Kolsteren, P., De Saeger, S., De Meulenaer, B., 2014. Public health risk associated with the co-occurrence of mycotoxins in spices consumed in Sri Lanka. Food and chemical toxicology : an international journal published for the British Industrial Biological Research Association 74, 240-248. 
Table 1. Maximum residue levels for mycotoxins in foodstuffs, according the EU's legislation (EC, 2006)

\begin{tabular}{|c|c|c|}
\hline Mycotoxin & $\begin{array}{l}\text { MRLs } \mu \mathrm{g} / \mathrm{kg} \\
(\mathrm{EC}, 2006)\end{array}$ & Commodities \\
\hline & 0.1 & Processed cereal-based baby food \\
\hline Aflatoxin $B_{1}$ & $\begin{array}{l}2.0-12 \\
\text { Sum of aflatoxins }\left(B_{1},\right. \\
\left.B_{2}, G_{1} \text {, and } G_{2}\right): \\
4.0-15.0\end{array}$ & Nuts and cereals \\
\hline Deoxynivalenol & $\begin{array}{l}200 \\
500-1750\end{array}$ & $\begin{array}{l}\text { Processed cereal-based baby food } \\
\text { Processed / unprocessed cereals, bread, } \\
\text { pasta, breakfast cereals }\end{array}$ \\
\hline $\begin{array}{l}\text { Fumonisin } \mathrm{B}_{1} \\
\text { Fumonisin } \mathrm{B}_{2}\end{array}$ & $\begin{array}{l}200 \\
800 \\
1000 / 4000\end{array}$ & $\begin{array}{l}\text { Processed maize-based baby food } \\
\text { Maize-based breakfast cereals } \\
\text { Maize / unprocessed maize }\end{array}$ \\
\hline Patulin & $10-50$ & $\begin{array}{l}\text { Fruit juices, apple products, baby food other } \\
\text { than processed cereal-based foods }\end{array}$ \\
\hline Ochratoxin A & $\begin{array}{l}0.5 \\
3.0 / 5.0 \\
10.0 \\
15 / 20 / 80\end{array}$ & $\begin{array}{l}\text { Processed cereal-based baby food } \\
\text { Processed / unprocessed cereals } \\
\text { Dried vine fruit } \\
\text { Spices / liquorice root / extract }\end{array}$ \\
\hline Zearalenone & $\begin{array}{l}20 \\
50 \\
75-350\end{array}$ & $\begin{array}{l}\text { Processed cereal-based baby food } \\
\text { Bread, biscuits, breakfast cereals } \\
\text { Processed / unprocessed cereals }\end{array}$ \\
\hline T-2 and HT- 2 a & $\begin{array}{l}15 \\
25-200 \\
1000\end{array}$ & $\begin{array}{l}\text { Cereal-based foods for infants and young } \\
\text { children } \\
\text { Cereal products for human consumption and } \\
\text { raw cereals (except oats) } \\
\text { Oats (with husk) }\end{array}$ \\
\hline
\end{tabular}

a According to the Recommendation of the European Commissión (indicative levels) (EC, 2013) 
Table 2. Mycotoxin levels (ng/g) in gofio samples.

\begin{tabular}{|c|c|c|c|c|c|c|c|c|c|c|c|c|c|c|c|c|c|c|c|c|}
\hline & & & & \multicolumn{10}{|c|}{ RAW MATERIAL } & \multicolumn{7}{|c|}{ MODE OF PRODUCTION } \\
\hline & \multicolumn{3}{|c|}{$\begin{array}{l}\text { All Samples } \\
(\mathrm{n}=94)\end{array}$} & \multicolumn{3}{|c|}{$\begin{array}{c}\text { Maize } \\
(n=46)\end{array}$} & \multicolumn{3}{|c|}{$\begin{array}{c}\text { Wheat } \\
(n=23)\end{array}$} & \multicolumn{3}{|c|}{$\begin{array}{l}\text { Mixed cereals } \\
(\mathrm{n}=26)\end{array}$} & \multirow[b]{2}{*}{$P^{a}$} & \multicolumn{3}{|c|}{$\begin{array}{l}\text { Conventional } \\
(n=62)\end{array}$} & \multicolumn{2}{|c|}{$\begin{array}{l}\text { Organic } \\
(n=32)\end{array}$} & \multirow[b]{2}{*}{$\begin{array}{l}\text { Freq } \\
(\%)\end{array}$} & \multirow[b]{2}{*}{$P^{b} / P^{c}$} \\
\hline & Median & range & $\begin{array}{l}\text { Freq } \\
(\%)\end{array}$ & Median & range & $\begin{array}{l}\text { Freq } \\
(\%)\end{array}$ & Median & range & $\begin{array}{l}\text { Freq } \\
(\%)\end{array}$ & Median & range & $\begin{array}{l}\text { Freq } \\
(\%)\end{array}$ & & Median & range & $\begin{array}{l}\text { Freq } \\
(\%)\end{array}$ & Median & range & & \\
\hline $\mathbf{A F B}_{1}$ & 0.02 & $\begin{array}{l}\text { N.D. - } \\
0.17\end{array}$ & 22.3 & 0.00 & $\begin{array}{c}\text { N.D. - } \\
0.08\end{array}$ & 17.4 & 0.01 & $\begin{array}{l}\text { N.D. - } \\
0.08\end{array}$ & 26.1 & 0.01 & $\begin{array}{c}\text { N.D. - } \\
0.17\end{array}$ & 34.6 & n.s. & 0.01 & $\begin{array}{l}\text { N.D. - } \\
0.17\end{array}$ & 22.2 & 0.02 & $\begin{array}{c}\text { N.D. - } \\
0.11\end{array}$ & 27.3 & n.s. \\
\hline $\mathbf{A F B}_{2}$ & 0.01 & $\begin{array}{l}\text { N.D. - } \\
0.07\end{array}$ & 21.7 & 0.00 & $\begin{array}{l}\text { N.D. - } \\
0.04\end{array}$ & 15.2 & 0.00 & $\begin{array}{l}\text { N.D. - } \\
0.04\end{array}$ & 30.4 & 0.01 & $\begin{array}{l}\text { N.D. - } \\
0.07\end{array}$ & 34.6 & n.s. & 0.01 & $\begin{array}{l}\text { N.D. - } \\
0.07\end{array}$ & 23.6 & 0.01 & $\begin{array}{l}\text { N.D. - } \\
0.06\end{array}$ & 26.0 & n.s. \\
\hline $\mathbf{A F G}_{1}$ & 0.00 & $\begin{array}{l}\text { N.D. - } \\
0.12\end{array}$ & 8.5 & 0.00 & $\begin{array}{l}\text { N.D. - } \\
0.11\end{array}$ & 6.5 & 0.00 & $\begin{array}{l}\text { N.D. - } \\
0.12\end{array}$ & 17.4 & 0.00 & $\begin{array}{l}\text { N.D. - } \\
0.05\end{array}$ & 11.5 & n.s. & 0.00 & $\begin{array}{l}\text { N.D. - } \\
0.09\end{array}$ & 8.3 & 0.00 & $\begin{array}{l}\text { N.D. - } \\
0.12\end{array}$ & 13.0 & n.s. \\
\hline $\mathbf{A F G}_{2}$ & 0.00 & $\begin{array}{l}\text { N.D. - } \\
0.06\end{array}$ & 7.4 & 0.00 & $\begin{array}{l}\text { N.D. - } \\
0.05\end{array}$ & 6.5 & 0.00 & $\begin{array}{l}\text { N.D. - } \\
0.06\end{array}$ & 17.4 & 0.00 & $\begin{array}{l}\text { N.D. - } \\
0.03\end{array}$ & 4,7 & n.s. & 0.00 & $\begin{array}{l}\text { N.D. - } \\
0.05\end{array}$ & 8.3 & 0.00 & $\begin{array}{l}\text { N.D. - } \\
0.06\end{array}$ & 13.0 & $n . s$ \\
\hline $\mathbf{F B}_{1}$ & 5.19 & $\begin{array}{l}\text { N.D. - } \\
140.9\end{array}$ & 70.2 & 4.12 & $\begin{array}{l}\text { N.D. - } \\
70.02\end{array}$ & 67.4 & 4.23 & $\begin{array}{l}\text { N.D. - } \\
140.9\end{array}$ & 69.6 & 8.71 & $\begin{array}{l}\text { N.D. - } \\
76.47\end{array}$ & 80.8 & n.s. & 4.92 & $\begin{array}{l}\text { N.D. - } \\
140.9\end{array}$ & 65.3 & 6.19 & $\begin{array}{l}\text { N.D. - } \\
42.14\end{array}$ & 86.9 & $\begin{array}{l}\text { n.s. / } \\
0.035\end{array}$ \\
\hline $\mathbf{F B}_{2}$ & 4.03 & $\begin{array}{l}\text { N.D. - } \\
37.42\end{array}$ & 65.9 & 3.33 & $\begin{array}{l}\text { N.D. - } \\
13.45\end{array}$ & 56.5 & 3.54 & $\begin{array}{l}\text { N.D. - } \\
37.42\end{array}$ & 69.6 & 6.51 & $\begin{array}{l}\text { N.D. - } \\
14.03\end{array}$ & 84.6 & n.s. & 4.02 & $\begin{array}{l}\text { N.D. - } \\
37.42\end{array}$ & 58.3 & 4.06 & $\begin{array}{l}\text { N.D. - } \\
14.03\end{array}$ & 91.3 & $\begin{array}{l}\text { n.s. / } \\
0.008\end{array}$ \\
\hline OTA & 0.00 & $\begin{array}{l}\text { N.D. - } \\
0.31\end{array}$ & 2.2 & 0.00 & $\begin{array}{l}\text { N.D. - } \\
0.33\end{array}$ & 4.3 & - & - & - & - & - & - & n.s. & - & - & - & 0.00 & $\begin{array}{l}\text { N.D. - } \\
0.31\end{array}$ & 8.7 & n.s. \\
\hline DON & 1.43 & $\begin{array}{l}\text { N.D. - } \\
92.48\end{array}$ & 33.0 & 1.25 & $\begin{array}{l}\text { N.D. - } \\
92.28\end{array}$ & 26.8 & 1.52 & $\begin{array}{l}\text { N.D. - } \\
35.41\end{array}$ & 41.7 & 1.25 & $\begin{array}{l}\text { N.D. - } \\
75.61\end{array}$ & 38.5 & n.s. & 1.42 & $\begin{array}{l}\text { N.D. - } \\
92.28\end{array}$ & 29.2 & 1.25 & $\begin{array}{l}\text { N.D. - } \\
75.61\end{array}$ & 47.8 & $\begin{array}{c}0.024 \\
/ \\
0.032\end{array}$ \\
\hline ZEA & 0.02 & $\begin{array}{l}\text { N.D. - } \\
9.92\end{array}$ & 42.5 & 0.02 & $\begin{array}{l}\text { N.D. - } \\
9.92\end{array}$ & 43.5 & 0.01 & $\begin{array}{l}\text { N.D. - } \\
1.84\end{array}$ & 39.1 & 0.02 & $\begin{array}{l}\text { N.D. - } \\
8.80\end{array}$ & 50.0 & n.s. & 0.01 & $\begin{array}{l}\text { N.D. - } \\
6.27\end{array}$ & 31.9 & 0.19 & $\begin{array}{l}\text { N.D. - } \\
9.92\end{array}$ & 78.3 & $\begin{array}{c}0.006 \\
/ \\
0.007\end{array}$ \\
\hline
\end{tabular}

a Comparison among three groups

b Comparison between concentrations

c Comparison between frequencies of detection 
Table 3. Estimated daily intake and risk characterization of Mycotoxin exposure through the consumption of gofio

\begin{tabular}{|c|c|c|c|c|c|c|c|c|}
\hline \multirow{3}{*}{ Mycotoxin } & \multicolumn{8}{|c|}{ AVERAGE CONSUMPTION } \\
\hline & \multicolumn{4}{|c|}{ ADULTS } & \multicolumn{4}{|c|}{ CHILDREN } \\
\hline & \multicolumn{2}{|c|}{$\begin{array}{c}\text { EXPOSURE } \\
\text { (ng/kg bw/day) }\end{array}$} & \multicolumn{2}{|c|}{ \% TDI } & \multicolumn{2}{|c|}{$\begin{array}{c}\text { EXPOSURE } \\
\text { (ng/kg bw/day) }\end{array}$} & \multicolumn{2}{|c|}{$\%$ TDI } \\
\hline$\sum$ Aflatoxins a & 0.02 & $0.01-0.12$ & 2.33 & $1.98-11.91$ & 0.04 & $0.02-0.19$ & 3.67 & $3.12-18.81$ \\
\hline$\sum$ Fumonisins $\mathrm{b}$ & 4.40 & $0.22-77.06$ & 0.22 & $0.01-3.85$ & 7.47 & $0.37-131.1$ & 0.37 & $0.02-6.55$ \\
\hline Ochratoxin A & 0.00 & $0.00-0.13$ & 0.06 & $0.03-0.76$ & 0.00 & $0.00-0.22$ & 0.11 & $0.07-1.29$ \\
\hline Deoxinivalenol & 0.54 & $0.38-39.88$ & 0.05 & $0.03-3.99$ & 0.92 & $0.68-67.81$ & 0.09 & $0.09-6.78$ \\
\hline Zearalenone & 0.01 & $0.00-4.28$ & 0.00 & $0.00-1.71$ & 0.01 & $0.01-7.29$ & 0.00 & $0.00-2.91$ \\
\hline
\end{tabular}

95 th PERCENTILE CONSUMPTION

\begin{tabular}{|c|c|c|c|c|c|c|c|c|}
\hline \multirow[b]{3}{*}{ Mycotoxin } & \multicolumn{4}{|c|}{ ADULTS } & \multicolumn{4}{|c|}{ CHILDREN } \\
\hline & \multicolumn{2}{|c|}{$\begin{array}{c}\text { EXPOSURE } \\
\text { (ng/kg bw/day) }\end{array}$} & \multicolumn{2}{|c|}{$\%$ TDI } & \multicolumn{2}{|c|}{$\begin{array}{c}\text { EXPOSURE } \\
\text { (ng/kg bw/day) }\end{array}$} & \multicolumn{2}{|c|}{$\%$ TDI } \\
\hline & EDI & LB - UB & Median & Range & EDI & LB - UB & Median & Range \\
\hline$\sum$ Fumonisins ${ }^{b}$ & 11.93 & $0.59-209.2$ & 0.60 & $0.03-10.46$ & 12.23 & $0.61-214.3$ & 0.61 & $0.03-10.72$ \\
\hline Ochratoxin A & 0.00 & $0.00-0.35$ & 0.17 & $0.11-2.06$ & 0.00 & $0.00-0.36$ & 0.18 & $0.12-2.11$ \\
\hline Deoxinivalenol & 1.47 & $1.47-108.3$ & 0.15 & $0.15-10.83$ & 1.50 & $1.50-110.9$ & 0.15 & $0.15-11.09$ \\
\hline Zearalenone & 0.01 & $0.01-11.63$ & 0.01 & $0.00-4.65$ & 0.02 & $0.01-11.92$ & 0.01 & $0.00-4.77$ \\
\hline
\end{tabular}

a "Total aflatoxins" in a regulatory sense refers to the sum of the concentrations of four aflatoxins: AFB1 + AFB2 + AFG1 + AFG2.

$b$ "Total fumonisins" in a regulatory sense refers to the sum of the concentrations of three fumonisins: FB1 + FB2 + FB3. As in this work we did not measure the concentrations of FB3, only the sum of FB1 + FB" is presented 

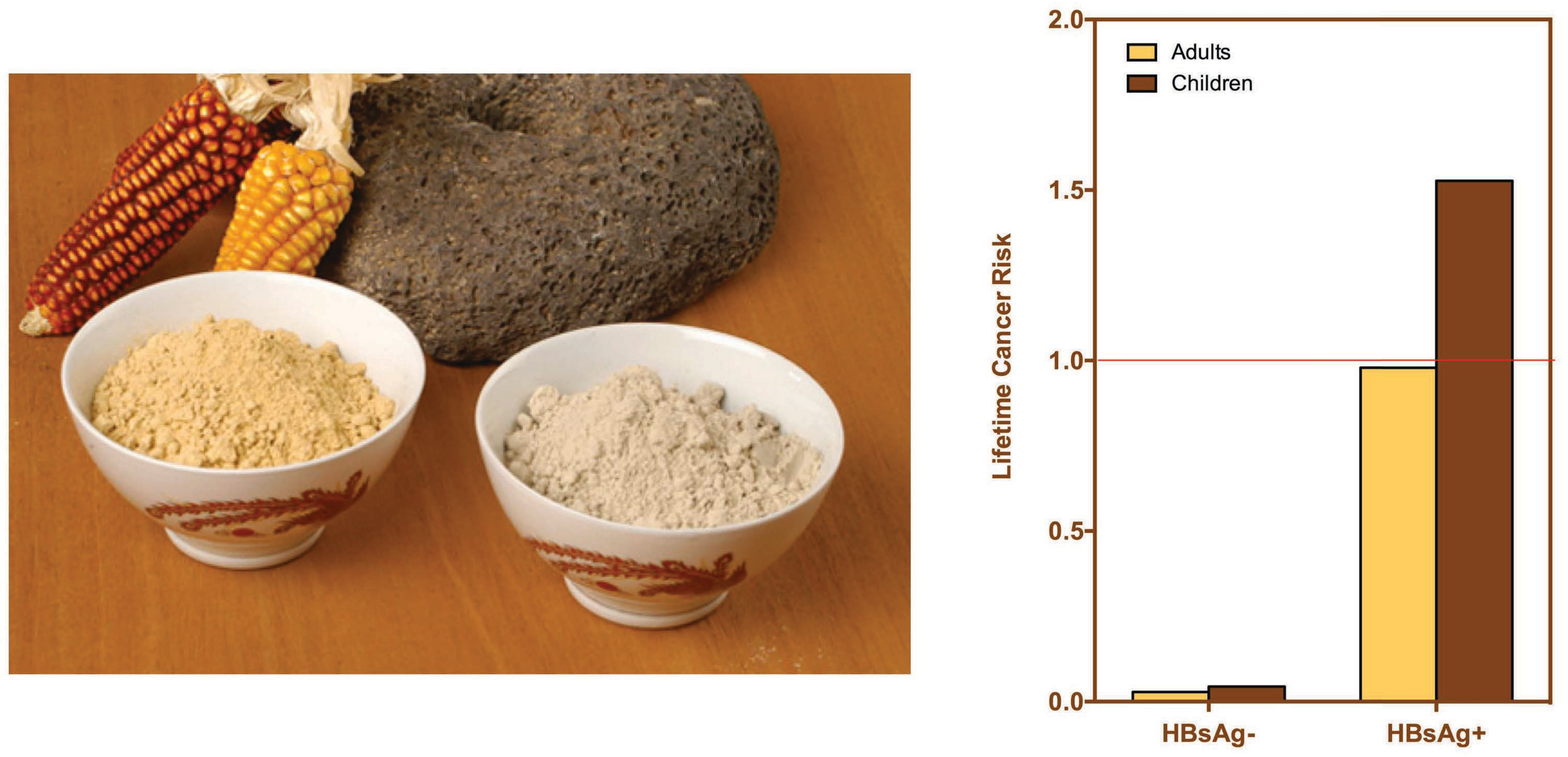